\title{
Size distribution and monthly variation of ovarian development for the female blue swimmer crab, Portunus pelagicus in Beibu Gulf, off south China
}

\author{
Zhijun Liu ${ }^{1,2 \dagger}$, Xugan $\mathrm{Wu}^{1,2 \dagger}$, Wei Wang ${ }^{1}$, Binlun Yan ${ }^{2}$, Yongxu Cheng ${ }^{1, \bigotimes}$ \\ ${ }^{1}$ Key Laboratory of Exploration and Utilization of Aquatic Genetic Resources, Shanghai Ocean University, No 999 \\ Huchenghuan Road, Lingang New District, Shanghai 201306, China. E-mail: chengyongxucrablab@ hotmail.com \\ ${ }^{2}$ Jangsu Key Laboratory of Marine Biotechnology, Huaihai Institute of Technology, Lianyungang 222005, China.
}

$\dagger$ Those authors contributed equally to this work.

\begin{abstract}
Summary: The present study was conducted to investigate the size distribution and seasonality variation of ovarian development for females of the blue swimmer crab, Portunus pelagicus, from Beibu Gulf, China. The results show that, based on pubertal moult, gonadosomatic index (GSI), morphology and histological configurations, the ovarian development cycle of $P$. pelagicus can be divided into five stages; Stage I, dominated by oogonia with some previtellogenic oocytes and endogenous vitellogeic oocytes; Stage II, dominated by endogenous vitellogenic oocytes with some previtellogeic oocytes and oogonia; Stage III, dominated by exogenous vitellogeic oocytes; Stage IV, of nearly mature oocytes; and Stage V, of mature oocytes with fully ripened ovary. GSI increased significantly during the ovarian development $(P<0.05)$, while the hepatosomatic index (HSI) appeared to decrease. Thus, a significant negative correlation was found between GSI and HSI $(\mathrm{P}<0.01)$. The smallest carapace width of a mature female and that at which $50 \%$ of females reach maturity were $79.2 \mathrm{~mm}$ and $108.2 \mathrm{~mm}$, respectively. The carapace width and body weight of the dominant size class ranged between 86 and $115 \mathrm{~mm}$ and 40 and $120 \mathrm{~g}$, respectively. Furthermore, the highest GSI of female P. pelagicus was found in March, while the peak of ovigerous females was found in April.
\end{abstract}

Keywords: blue swimmer crab; ovarian development; size at maturity; seasonality.

Distribución del tamaño y variación mensual del desarrollo ovárico del cangrejo azul hembra, Portunus pelagicus en el golfo de Beibu, frente al sur de China

Resumen: Este estudio se realizó para investigar la distribución del tamaño y la estacionalidad de desarrollo ovárico del cangrejo azul hembra, Portunus pelagicus en el golfo de Beibu, China. Los resultados muestran que, sobre la base de la muda de la pubertad, el GSI (índice gonadosomático), la morfología y las configuraciones histológicos y el ciclo del desarrollo ovárico de $P$. pelagicus puede dividirse en cinco etapas. Etapa I: La fase de oogonia (OG) dominaba con algunos ovocitos previtelogeicos (PR) y ovocitos vitelogeicos endógenos (EN); Etapa II: fase de EN dominaba con algunos PR y OG; Etapa III: la fase de ovocitos vitelogeicos exógenos (EX) era dominante; Etapa IV: fase de ovocitos casi maduros (NO); Etapa V: fase de ovocitos maduros (MO) y maduración completa del ovario. El índice gonadosomático (GSI) aumentó significativamente durante el desarrollo del ovario $(\mathrm{P}<0.05)$, mientras que el índice hepatosomático (HSI) parecía disminuir. Por lo tanto, se encontró una correlación negativa significativa entre GSI y HSI $(\mathrm{P}<0.01)$. La menor anchura del caparazón $(\mathrm{CW})$ de una hembra madura y CW del $50 \%$ de las hembras maduras eran $79.2 \mathrm{~mm}$ y $108.2 \mathrm{~mm}$, respectivamente. La CW y el peso corporal de la clase de tamaño dominante oscilaban entre 86-115 mm y 40-120 g respectivamente. Por otra parte, el GSI de la hembra más grande de $P$. pelagicus se encontró en marzo, mientras que el pico de las hembras ovígeras se produjo en abril en la población del golfo de Beibu .

Palabras clave: cangrejo azul; desarrollo ovárico; talla de madurez; estacionalidad.

Citation/Como citar este artículo: Liu Z., Wu X., Wang W., Yan B, Cheng Y. 2014. Ovarian development, size distribution and monthly variation of the female blue swimmer crab, Portunus pelagicus in Beibu Gulf, off south China. Sci. Mar. 78(2): 257-268. doi: http://dx.doi.org/10.3989/scimar.03919.24A

Editor: C. Zeng.

Received: July 12, 2013. Accepted: January 15, 2014. Published: May 30, 2014.

Copyright: () 2014 CSIC. This is an open-access article distributed under the Creative Commons Attribution-Non Commercial Lisence (by-nc) Spain 3.0. 


\section{INTRODUCTION}

The blue swimmer crab, Portunus pelagicus Linnaeus 1758 , is widely distributed in the Indo-Pacific, particularly in tropical and subtropical waters, and supports important fisheries in many countries within the region (Xiao and Kumar 2004, Romano and Zeng 2008). Due to high demand, unique taste and availability in all seasons, the species is popular and has a high market demand (Sumpton et al. 1994, Wu et al. 2010). In China, it is mainly distributed in the East Sea and South Sea of western Pacific (Wang et al. 2001) and the annual fishing production is around $80000 \mathrm{t}$ of $P$. pelagicus each year (Bureau of Fisheries 2010). Beibu Gulf is the historical centre for the blue swimmer crab fishery in China; with annual landing production estimated around $20000 \mathrm{t}$ per year (Wang et al. 2001, Bureau of Fisheries 2010). However, wild $P$. pelagicus has been overfished, and in the future, the expansion of $P$. pelagicus output depends on aquaculture and stock enhancement programmes (Maheswarudu et al. 2008, Dixon and Hooper 2009). Therefore, a better understanding of its reproductive biology would directly benefit the fisheries management as well as artificial propagation of $P$. pelagicus (Stewart et al. 2007, Johnson et al. 2010).

Many studies have been conducted on the reproductive biology of female $P$. pelagicus, including size of sexual maturity (Shields and Wood 1993; Smith et al. 2004; Johnson et al. 2010), changes of external features of the ovary (gross morphology and colouration) (Sumpton et al. 1994), anatomical changes of spermatheca (Bawab and El-sherief 1988), histological changes of ovary (Stewart et al. 2007), seasonal fluctuations of gonadosomatic index (GSI) (Pillay and Nair 1973, Sumpton et al. 1994), temporal changes in the proportion of gravid females (Shields and Wood 1993, Sukumaran and Neelakantan 1998, Kumar et al. 2003), fecundity and egg batches (Johnson et al. 2010, De Lestang et al. 2003a). However, the criteria of ovarian staging of $P$. pelagicus is inconsistent and unclear among the different publications (Sumpton et al. 1994, Stewart et al. 2007), making it difficult to apply these ovarian staging criteria for fisheries management aand to compare the results from different research reports (Stewart et al. 2007). The correlation of sexual maturity with gonadosomatic index (GSI), external features and ovarian histology could help wild fisheries managers and aquaculture specialists make informed decisions about their catches and extend the knowledge to breeding programmes of $P$. pelagicus. Therefore, a comprehensive method for ovarian staging, such as a combination of GSI, external features and ovarian histology, is required for the female $P$. pelagicus.

Previous studies on the reproductive biology of female $P$. pelagicus, have reported regional and areaspecific differences in size at sexual maturity, timing and length of female ovarian development, and spawning season (Shields and Wood 1993, Sumpton et al. 1994, Smith et al. 2004, Xiao and Kumar 2004, Johnson et al. 2010). Although the Beibu Gulf population of $P$. pelagicus supports the largest $P$. pelagicus fishery
(20\% of total landings) in China (Wang et al. 2001), no available publications could be found on female reproductive biology for the Beibu Gulf population of P. pelagicus.

The present study of the $P$. pelagicus population in Beibu Gulf was conducted with the aim of determining the following: (1) changes in gonadosomatic index (GSI), hepatosomatic index (HSI), gross morphology and histological features of the ovary during ovarian development; (2) the correlations of GSI and HSI, oocyte diameter and GSI; (3) size at ovarian maturity and pubertal moulting; (4) size distribution and frequency for the females after pubertal moulting; (5) seasonality of ovarian development and the percentage of ovigerous females.

\section{MATERIALS AND METHODS}

\section{Crab sampling}

Monthly samples of $P$. pelagicus were collected from the Beibu Gulf, near the northwest coast of Hainan Island (109 $45^{\prime} \mathrm{E}, 19^{\circ} 58^{\prime} \mathrm{N}$, Fig. 1) from September 2007 to May 2008. No samples were obtained from June to August 2008 due to the closed fishing season (May 16 to August 15). Thirty to seventy random female crabs were taken each month. All crabs were measured for carapace width (CW, including lateral spines) and body weight (BW). The live females of above $75 \mathrm{~mm} \mathrm{CW}$ ( $<75 \mathrm{~mm}$ is juvenile, Wang et al. 2001) were collected every month and air-lifted to the laboratory at Shanghai Ocean University, Shanghai, China.

\section{Crab dissection and ovarian staging}

In the laboratory, ovaries and hepatopancreas were dissected from the crabs. Their total weight was recorded and their GSI and HSI were calculated as the percentage of tissue wet weight relative to body wet weight. Photographs of the dissected ovary were taken using a digital camera (Canon Powershot A550). A small portion of ovaries were removed from each dissected ovary and fixed in Bouin's solution for 24

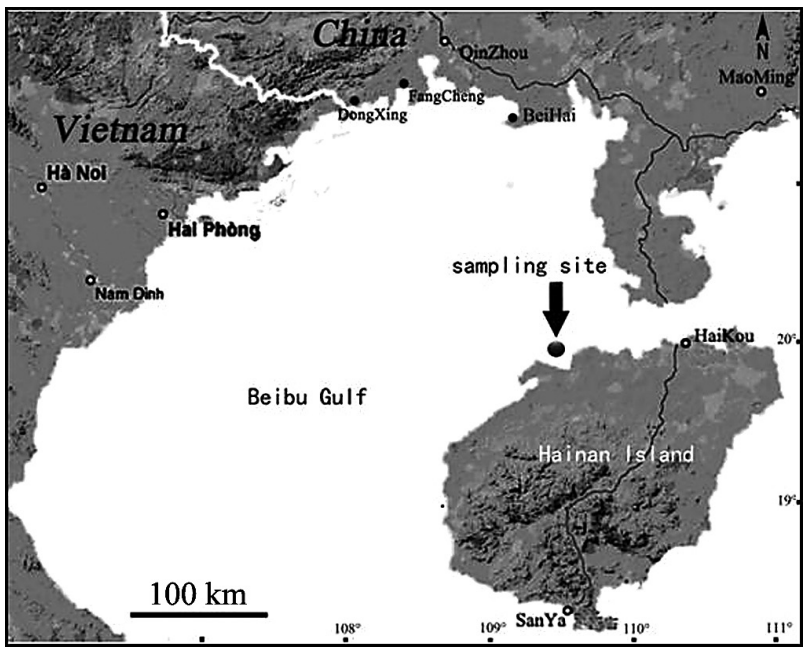

Fig. 1. - Map of Beibu Gulf, showing the sampling site. 
hours. The ovarian tissues were then progressively dehydrated in ascending concentrations of ethanol solutions and the dehydrated specimens were cleared with xylene before being embedded in paraffin wax (melting point: $56-58 \mathrm{C}$ ). Glass slides of ovaries were prepared (5-7 $\mu \mathrm{m})$ (Leica RM 2016, Leica Microsystems Inc., Bannockburn, IL, USA). The sections were then stained with haematoxylin-eosin, and histological observations and measurements were made under a light microscope (Olympus BX-41, Olympus Corporation, Shinjuku-ku, Tokyo, Japan). Microphotographs were taken with a digital camera (Nikon IDXM 1200, Nikon Co., Shinagawa-ku, Tokyo, Japan) equipped with an image manager software (Image-Pro Plus 6.0, Media Cybernetics Inc, Bethesda, MD, USA). Based on Wu et al. (2007): Gametocytes were classified into six categories: oogonia (OG), previtellogenic oocyte $(\mathrm{PR})$, endogenous vitellogenic oocyte (EN), exogenous vitellogenic oocyte (EX), near-mature oocyte (NO) and mature oocyte (MO). The diameter, nucleus and nucleolus of each type of gametocyte was then measured under a microscope (Olympus BX-41) while the nucleo-cytoplasmic ratio (NR) was calculated using the formula $\mathrm{NR}=$ Volume of nucleus/Volume of cell, where volume $=0.523 \times \mathrm{W}^{2} \times \mathrm{L}(\mathrm{W}$, maximum width; L, maximum length) (Wu et al. 2007). Thirty to fifty oocytes from each female were measured for various parameters and the relative frequency of the most advanced oocytes appearing in the ovarian sections became an important criteria for ovarian staging (Quinitio et al. 2007). The calculation for the percentage of each gametocyte types at each ovarian stage was based on 8-13 replicate females and ten slides were observed and calculated under the microscope for each female.

\section{Estimation of size at ovarian maturity}

A total of 324 females were used to examine size at ovarian maturity. The females with vitellogenic ovaries were considered to be mature individuals (ovarian developmental stages III-V; detailed staging information is shown in Table 2). To estimate the size at first maturity, the minimum $\mathrm{CW}$ was recorded for the females with the oval-shaped pleonal flap, which indicated that the females had finished the pubertal moult (Johnson et al. 2010). The CW at which 50\% $\left(\mathrm{CW}_{50}\right)$ of females were sexually mature was estimated by fitting a logistic regression curve to the percentage of mature $P$. pelagicus for each size class of $10 \mathrm{~mm}$ CW, as described by Johnson et al. (2010).

\section{Statistical analysis}

Data are presented as mean \pm standard error (SE). The homogeneity of variance of data was tested with Levene's test. When necessary, arcsine-square root or logarithmic transformation was performed prior to analysis. Statistical analysis was conducted using one-way analysis of variance (ANOVA) and Tukey's multiple range test was used to detect significant differences $(\mathrm{P}<0.05)$. When a normal distribution and/or homogeneity of variances was not achieved, data were subjected to the Kruskal-Wallis H non-parametric test, followed by the Games-Howell non-parametric multiple comparison test. All analyses were performed using an SPSS statistic package (version 12.0).

\section{RESULTS}

\section{Ovary-morphological and histological changes during maturation}

Six types of gametocytes of different developmental stages, i.e. OG, PR, EN, EX, NO and MO, were observed during the ovary maturation of $P$. pelagicus (Fig. 2). The details of cell diameter, nucleus diameter, nucleocytoplasmic ratio and volume of the six different-type gametocytes for female $P$. pelagicus are presented in the Table 1. With the development of germinal cells, the cell diameter, nucleus diameter and oocyte volume all increased substantially, but a significant decrease in the short diameter of the nucleus was found when oocytes developed from NO to MO. Meanwhile, the nucleocytoplasmatic ratio also showed a significant decrease from 0.56 to 0.0004 with the development from $\mathrm{OG}$ to $\mathrm{MO}(\mathrm{P}<0.01)$. Based on the pubertal moult, gonadosomatic index (GSI), gross external morphology and histological changes in the ovaries, the ovarian maturation of $P$. pelagicus can be divided into five stages (Table 2).

Stage I: Most females (>90\%) in this stage were yet to undergo pubertal moult, with a triangular-shaped pleonal flap (Fig. 3A). The ovary was small and slightly convoluted, appearing transparent or translucent (Fig. 3C). In this stage, the ovary was sometimes difficult to recognize and was separated from the heptopancreas. The GSI of stage I ovaries ranged from 0.02 to 0.30 . Histological examination revealed that the dominant types of gametocytes in stage I ovaries OG $(61.00 \%)$, PR (25.93\%) and EN (11.96\%). Many follicle cells were found to be distributed in the ovarian lobes and the interspace between ovarian lobes (Fig. 4A). A number of PR

Table 1. - Various parameters of different types of gametocyte cells observed during the ovarian maturation of Portunus pelagicus. Values are presented as mean \pm SE. Different superscript letters within the same row indicates significant differences $(\mathrm{P}<0.05)$.

\begin{tabular}{|c|c|c|c|c|c|c|}
\hline Parameter & Oogonia & $\begin{array}{l}\text { Previtellogenic } \\
\text { oocyte }\end{array}$ & $\begin{array}{c}\text { Endogenous. } \\
\text { vitellogenic } \\
\text { oocyte }\end{array}$ & $\begin{array}{c}\text { Exogenous } \\
\text { vitellogenic } \\
\text { oocyte }\end{array}$ & $\begin{array}{c}\text { Nearly mature } \\
\text { oocyte }\end{array}$ & Mature oocyte \\
\hline Long diameter of oocyte $(\mu \mathrm{m})$ & $11.62 \pm 0.14^{\mathrm{a}}$ & $22.62 \pm 0.46^{\mathrm{a}}$ & $58.58 \pm 2.01^{\mathrm{b}}$ & $115.65 \pm 2.79^{c}$ & $237.67 \pm 8.12^{\mathrm{d}}$ & $310.84 \pm 5.04^{\mathrm{e}}$ \\
\hline Short diameter of oocyte $(\mu \mathrm{m})$ & $10.37 \pm 0.18^{a}$ & $17.51 \pm 0.19^{\mathrm{a}}$ & $41.29 \pm 1.62^{b}$ & $86.12 \pm 2.08^{c}$ & $173.82 \pm 5.40^{\mathrm{d}}$ & $237.48 \pm 4.32^{\mathrm{e}}$ \\
\hline Long diameter of nucleus $(\mu \mathrm{m})$ & $9.61 \pm 0.19^{\mathrm{a}}$ & $15.28 \pm 0.45^{\mathrm{b}}$ & $25.27 \pm 0.94^{c}$ & $32.34 \pm 1.47^{\mathrm{d}}$ & $28.81 \pm 1.13^{\mathrm{cd}}$ & $26.31 \pm 1.20^{\mathrm{c}}$ \\
\hline Short diameter of nucleus ( $\mu \mathrm{m})$ & $8.52 \pm 0.16^{\mathrm{a}}$ & $12.74 \pm 0.26^{b}$ & $20.61 \pm 0.88^{c}$ & $7.60 \pm 0.35^{\mathrm{d}}$ & $19.93 \pm 0.84^{\mathrm{c}}$ & $15.92 \pm 0.69^{\mathrm{b}}$ \\
\hline Nucleocytoplasmic ratio & $0.56 \pm 0.073^{\mathrm{f}}$ & $0.36 \pm 0.071^{\mathrm{e}}$ & $0.12 \pm 0.059^{\mathrm{d}}$ & $0.03 \pm 0.01^{\mathrm{c}}$ & $0.002 \pm 0.001^{b}$ & $0.0004 \pm 0.0003^{\mathrm{a}}$ \\
\hline Oocyte volume $\left(\times 10^{5} \mu \mathrm{m}^{3}\right)$ & $0.007 \pm 0.000^{\mathrm{f}}$ & $0.04 \pm 0.01^{\mathrm{e}}$ & $0.59 \pm 0.07^{\mathrm{d}}$ & $4.68 \pm 0.29^{c}$ & $41.75 \pm 3.56^{\mathrm{b}}$ & $93.88 \pm 4.39^{\mathrm{a}}$ \\
\hline
\end{tabular}



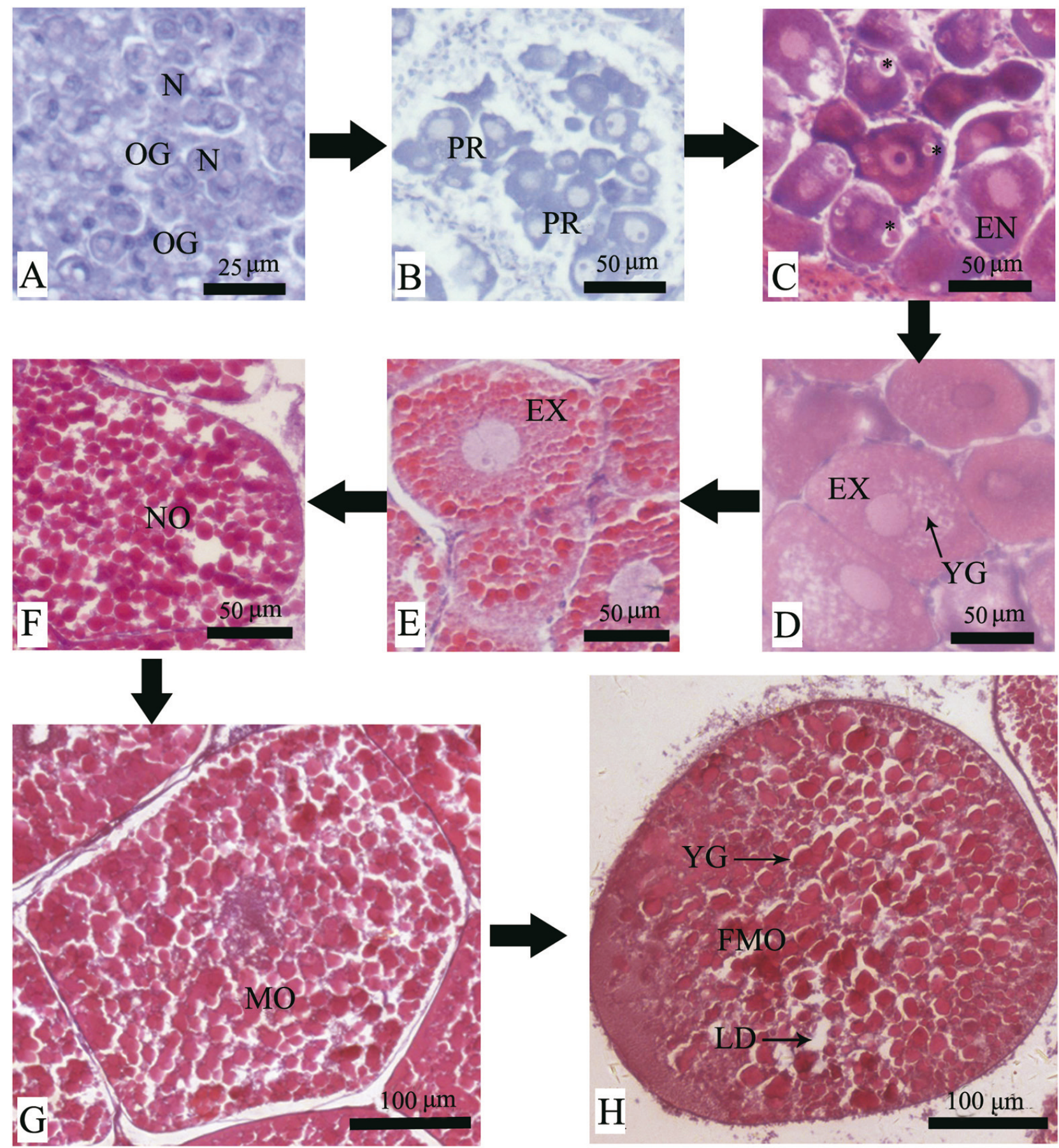

Fig. 2. - Histology of six types of oogenetic cells during the ovarian development of Portunus pelagicus. A, oogonia (OG), with basophilic chromosomes condensed in the nucleus (N); B, previtellogenic oocyte (PR), having bluish cytoplasm and without yolk granules; C, endogenous vitellogenic oocyte (EN), with some eosinophilic components (*); D, early exogenous vitellogenic oocyte (EX), showing eosinophilic cytoplasm with many small yolk granules (YG); E, later EX, showing the large yolk granules (YG) and lipid droplet (LD) in cytoplasm; F, nearly mature oocyte (NO); G, mature oocyte (MO), with many large yolk globules (YG); H, free mature oocyte (FMO), which was separated from the follicle cells.

were surrounded by follicle cells, which were observed at the end of stage I (Fig. 4B). The cytoplasm was basophilic for all gametocytes types in this stage.

Stage II: At this ovarian stage most females had undergone pubertal moult and had an oval pleonal flap (Fig. 3B). The ovary colour had changed from milkywhite to off-white (Fig. 3D) and two parallel ovary mid-lobes were visible to the naked eye. The GSI of stage II ovaries ranged from 0.27 to 0.54 . The dominant oocyte types of stage II ovaries were EN (40.26\%), PR $(31.34 \%)$ and OG $(21.12 \%)$ (Fig. 4C). In the same follicle/germinal zone (a small spherical group of cells), the germ cells (EN) in the periphery of the zone had a more advanced development than the gametocytes in the middle zone. In this stage, the cytoplasm had become slightly eosinophilic due to the presence of small yolk globules, and the follicle cells had started to migrate to the periphery of germ zone. 


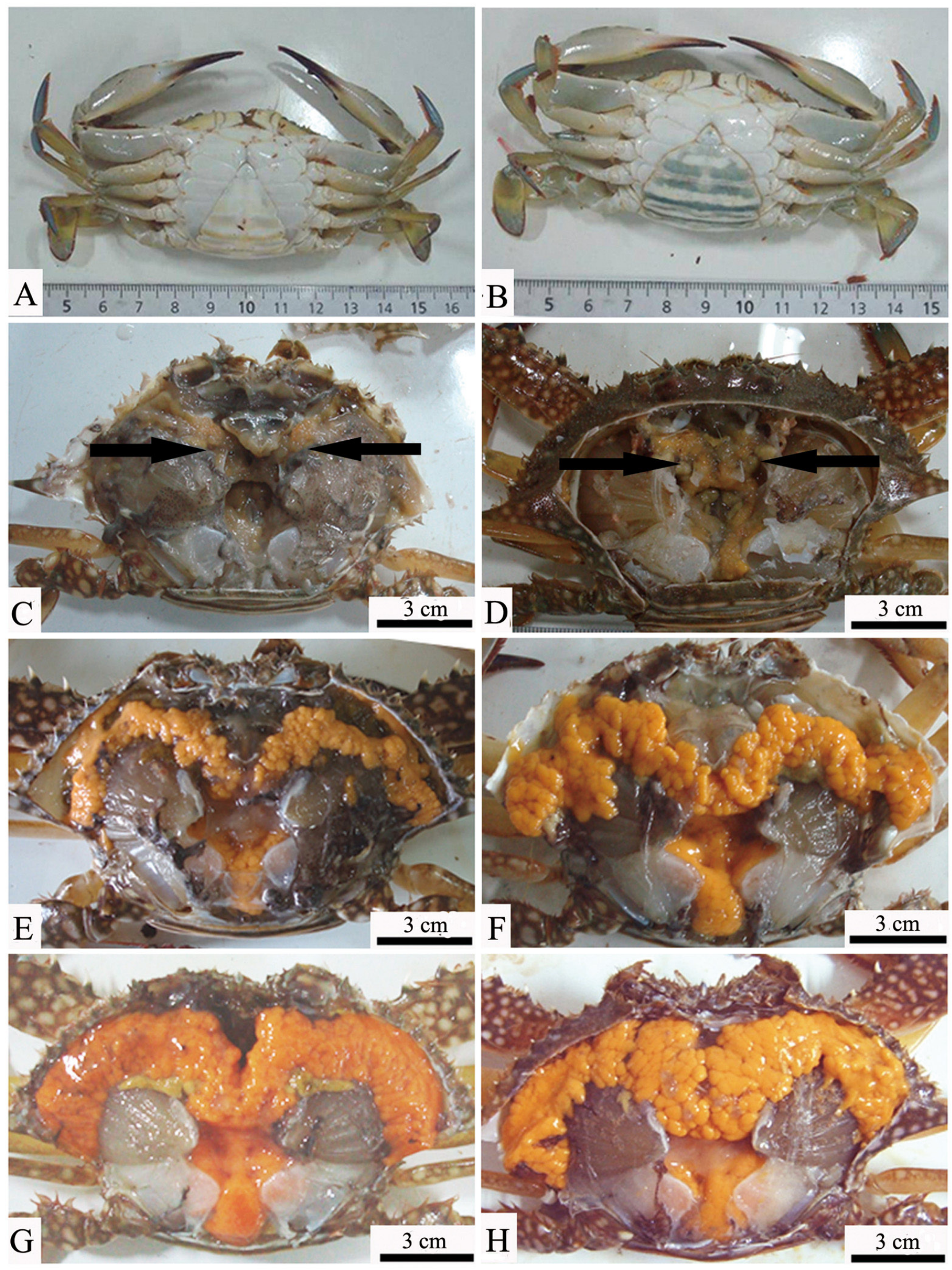

Fig. 3. - Changes in the abdominal shape and different stages of ovarian development in Portunus pelagicus. A, the abdominal shape of female Portunus pelagicus before puberty moult, showing a triangular abdomen; B, the abdominal shape of female Portunus pelagicus after puberty moult, showing a U-shaped abdomen; C, stage I ovary (arrow); D, stage II ovary (arrow); E, early stage III ovary; F, late stage III ovary; G, stage IV ovary; $\mathrm{H}$, stage V ovary. 

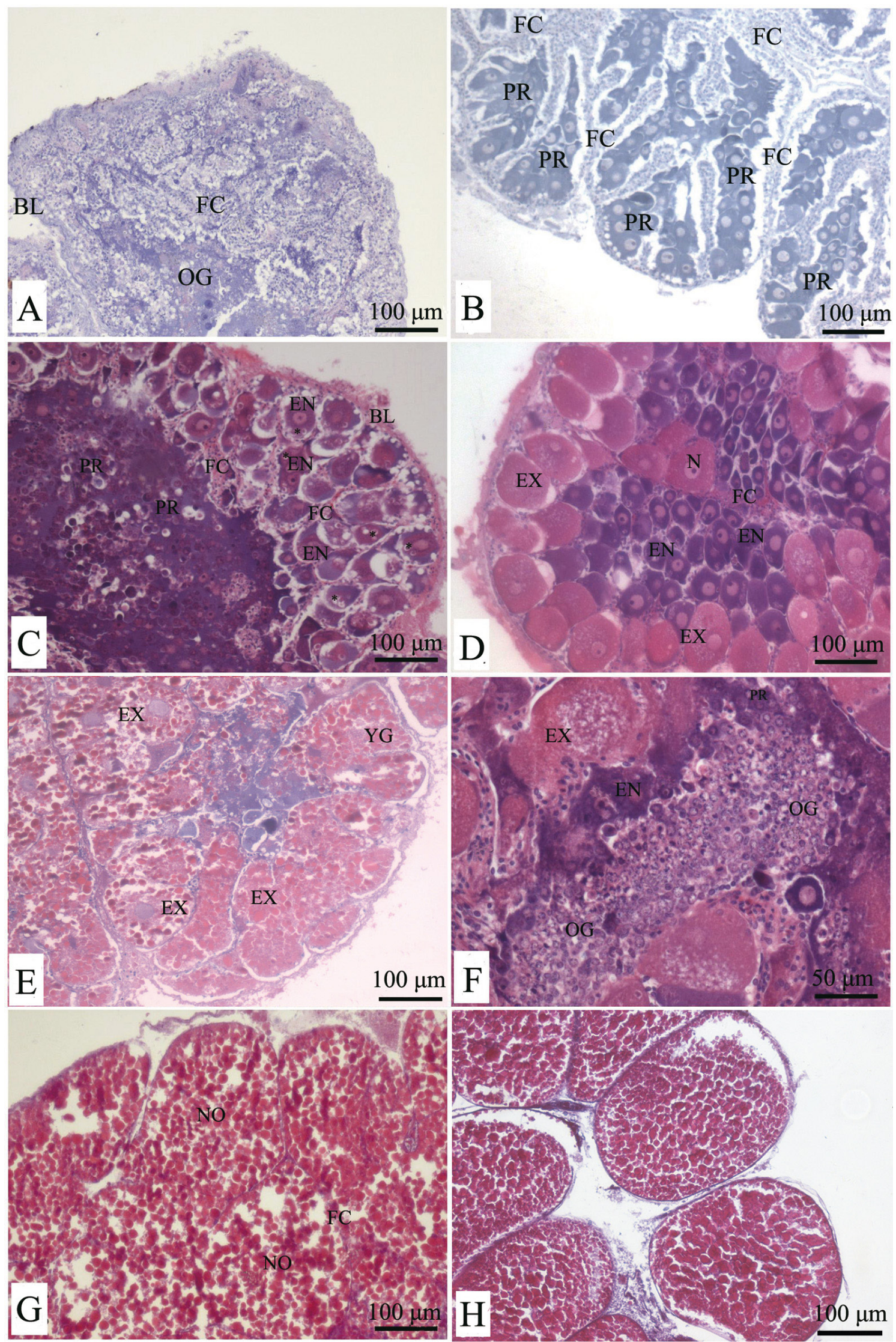

Fig. 4. - Ovarian histology of Portunus pelagicus during the reproductive cycle. A, early stage I ovary, showing oogonia (OG) and follicle cell (FC); B, late stage I ovary, showing previtellogeic oocytes (PR) and FC; C, stage II ovary, showing EN and small eosinophilic components (*); D, early stage III ovary, showing EN and EX; E, late stage III ovary, showing EX with YG; F, stage III ovary, still containing OG zone between the EX; G, late stage IV, showing NO; H, late stage V, showing MO. 
Table 2. - The main features of different ovarian development stages during the ovarian maturation of Portunus pelagicus.

\begin{tabular}{|c|c|c|c|c|}
\hline $\begin{array}{l}\text { Ovarian } \\
\text { stages }\end{array}$ & External ovarian features & $\begin{array}{l}\text { Ovarian histological } \\
\text { features }\end{array}$ & $\operatorname{GSI}(\%)$ & $\begin{array}{c}\text { Pubertal } \\
\text { moult }\end{array}$ \\
\hline I & $\begin{array}{l}\text { Ovary is small and slightly con- } \\
\text { voluted, appears transparent, or } \\
\text { translucent. }\end{array}$ & $\begin{array}{l}\text { Oogonia and previtellogenic oocytes are the dominant } \\
\text { types while they have not been surrounded by follicle } \\
\text { cells. The cytoplasm is basophilic. }\end{array}$ & $0.02-0.30$ & $\begin{array}{l}\text { Most of them } \\
\text { are before }\end{array}$ \\
\hline II & $\begin{array}{l}\text { Ovary increases in size and ap- } \\
\text { pears milky-white to off-white in } \\
\text { colour. Two parallel ovary lobes } \\
\text { are easily eye-visible. }\end{array}$ & $\begin{array}{l}\text { Previtellogenic oocytes and endogenous vitellogenic } \\
\text { oocyte appear dominant. Small yolk globules start to } \\
\text { appear in exogenous vitellogenic oocytes and follicle } \\
\text { cells have migrated to the periphery of the follicle. }\end{array}$ & $0.27-0.54$ & Almost after \\
\hline III & $\begin{array}{l}\text { Ovary becomes light yellow or } \\
\text { yellow. The ovary starts to cover } \\
\text { parts of branchia and ovarian } \\
\text { lobules become more apparent. }\end{array}$ & $\begin{array}{l}\text { Exogenous vitellogenic oocytes are the dominant } \\
\text { oocytes in ovarian lobules while the minority of endog- } \\
\text { enous vitellogenic oocytes are located in the central } \\
\text { part of the follicle. Large yolk globules appear in cy- } \\
\text { toplasm at late stage III. Follicle cells are compressed } \\
\text { and closely surrounding the oocytes. }\end{array}$ & $0.38-4.54$ & Almost after \\
\hline IV & $\begin{array}{l}\text { Ovary shows yellow or bright } \\
\text { orange colouration, middle region } \\
\text { of ovary starts to cover part of the } \\
\text { stomach. }\end{array}$ & $\begin{array}{l}\text { Dominant oocytes are nearly mature oocytes. Small } \\
\text { yolk globules become apparent in the entire cytoplasm } \\
\text { and nucleus reduce in size and locate sideways. }\end{array}$ & $4.50-9.21$ & After \\
\hline $\mathrm{V}$ & $\begin{array}{l}\text { Ovary is deep yellow to red- } \\
\text { orange and reaches maximum } \\
\text { size. The middle region of ovary } \\
\text { covers the whole stomach. Ovar- } \\
\text { ian lobules appear swollen and } \\
\text { some mature oocytes become } \\
\text { easily detached from the ovarian } \\
\text { lobe. }\end{array}$ & $\begin{array}{l}\text { Most oocytes are fully mature and have the homogeni- } \\
\text { zation of yoke globules, which are distributed over the } \\
\text { entire cytoplasm. }\end{array}$ & $8.31-14.51$ & After \\
\hline
\end{tabular}

Stage III: The ovary appear light yellow or yellow and its size increased drastically compared with the early ovarian stage. The anterior region of two parallel ovary lobes had a conspicuous M shape (Fig. 3E, $3 \mathrm{~F})$. The central region of lobes enveloped the dorsal surface of the spermathecae. In advanced stage III, the ovary started to cover the basilar parts of the branchia and ovarian lobules become more visible (Fig. 3F). The GSI of stage III ovaries increased dramatically from 0.38 to 4.54 . The early stage III ovaries mainly contained EX (79.71\%) and EN (20.28\%). EX were localized in the periphery of each follicle (a small spherical group of cells) while EN were distributed in the central part of the follicle (Fig. 4D), where EX started to contain yolk granule (YG). The mean long diameter of EX was $107.28 \mu \mathrm{m}$ for the early stage III ovary and in the later stage III ovary the dominant oocyte type was EX filled with YG (Fig. 4E). Occasionally, a few OG and PR still existed between EX (Fig. 4F). The mean long diameter of EX was $168.54 \mu \mathrm{m}$ for the later stage III, significantly longer than that of early stage EX $(\mathrm{P}<0.05)$.

Stage IV: The ovary showed yellow to bright orange colouration. Ovary lobes occupied most available body cavities and the mid-lobes covered part of the stomach (Fig. 3G). The GSI of stage IV ovaries ranged from 4.50 to 9.21 and histological studies showed that this stage was dominated by NO. The mean long diameter of NO was $258.37 \mu \mathrm{m}$, significantly longer than the EX of stage III ovaries $(\mathrm{P}<0.05)$. In NO, the small YG became apparent in the entire cytoplasm of NO (Fig. 4G). The uniform presence of small YG was an indicator of NO development. The nuclecytoplasmic ratio of NO decreased more significantly than that of EX (Table 1) and the nucleus located peripherally was hardly recognizable in this stage (Fig. 4G). The follicle cells were not easily recognizable because of the crowding of the oocytes.
Stage V: Mature ovaries were deep yellow to redorange in colour and reached the maximum size, with the middle lobes covering the whole stomach (Fig. $3 \mathrm{H})$. The gastric, posterior and intestinal cavities were completely filled with the large central and posterior sections of the ovary. The ovarian lobules appeared swollen and some MO became easily detached from the ovarian lobe when handled (Fig. 4H). The histological sections showed the majority oocytes to be fully mature at this stage. The MO had the uniform YG, which were distributed evenly in the entire cytoplasm while the nucleus was small, located peripherally and not easy recognizable (Fig. 4H). In some cases, the MO were separated from the follicle cells, indicating that spawning was imminent (Fig. 4H).

\section{Changes in GSI, HSI and oocyte diameter during ovarian development}

During the ovarian maturation, the GSI increased with the ovarian development while the HSI was decreased (Table 3). The highest HSI was found in stage II. Within the same ovarian stage, the HSI varied significantly: e.g. the HSI ranged from 2.09 to 8.59 for stage I female crabs. Furthermore, a significantly negative correlation was found between GSI and HSI (Fig. 5, $\mathrm{n}=52, \mathrm{P}<0.001, \mathrm{r}=-0.484$ ). From ovarian stage III to $\mathrm{V}$ (exogenous vitellogenic phase), a significant positive correlation was found between GSI and long diameter of oocytes (Fig. $6, \mathrm{n}=32, \mathrm{P}<0.001$, $\mathrm{r}=0.956$ ).

\section{Size at sexual maturity}

In the present study, the minimum size at first maturity was $78.5 \mathrm{~mm} \mathrm{CW}$ based on ovarian development (stage III) and the size of the smallest berried crab was $79.2 \mathrm{~mm} \mathrm{CW}$. However, about $60 \%$ of females in the 
Table 3. - The gonadosomatic index (GSI) and heaptosomatic index (HSI) at different stages of ovary mature in Portunus pelagicus. Values are presented as mean \pm SE. Different superscript letters within a same row indicate significant differences $(\mathrm{P}<0.05)$.

\begin{tabular}{|c|c|c|c|c|c|}
\hline Ovarian stage & I & II & III & IV & $\mathrm{V}$ \\
\hline Sample number & 12 & 9 & 13 & 10 & 8 \\
\hline GSI (\%) & $0.18 \pm 0.02^{\mathrm{a}}$ & $0.39 \pm 0.04^{b}$ & $1.90 \pm 0.34^{\mathrm{c}}$ & $7.91 \pm 0.40^{\mathrm{d}}$ & $11.50 \pm 0.75^{\mathrm{e}}$ \\
\hline Range of GSI & $0.02-0.30$ & $0.27-0.54$ & $0.38-4.54$ & $4.50-9.21$ & $8.31-14.51$ \\
\hline $\operatorname{HSI}(\%)$ & $5.56 \pm 0.32^{b c}$ & $6.44 \pm 0.62^{c}$ & $4.46 \pm 0.40^{\mathrm{ab}}$ & $4.06 \pm 0.36^{\mathrm{a}}$ & $3.70 \pm 0.50^{\mathrm{a}}$ \\
\hline Range of HSI & $2.07-8.59$ & $2.50-8.49$ & $2.16-7.63$ & $2.32-6.23$ & $2.03-5.74$ \\
\hline
\end{tabular}

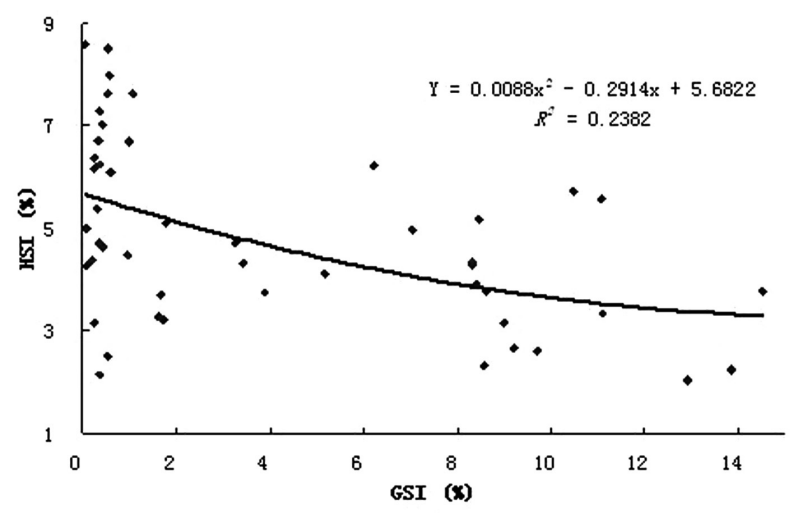

Fig. 5. - The correlation of gonadosomatic index (GSI) and hepatosomatic index (HSI) during the ovarian development of Portunus pelagicus.

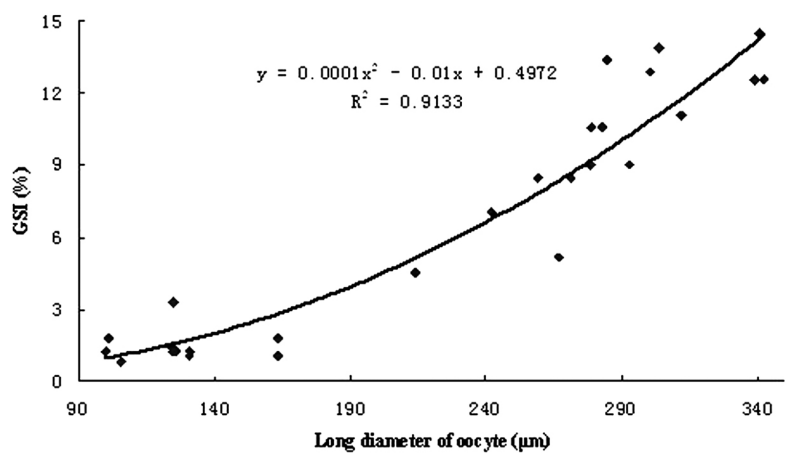

Fig. 6. - The correlation of mean long diameter of oocyte $(\mu \mathrm{m})$ and gonadosomatic index (GSI) during ovarian stage III to V of Portunus pelagicus. Each female had its own GSI and mean long diameter of its oocyte, and these data were used for the correlated analysis.

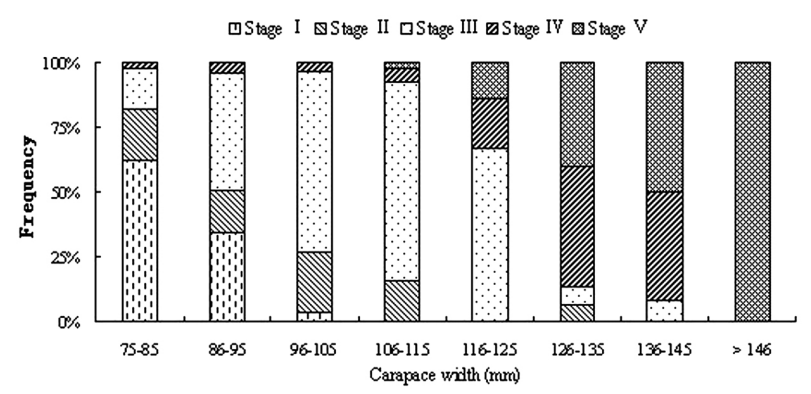

Fig. 7. - Frequency of occurrence of each ovarian developmental stage in different size classes of Portunus pelagicus in Beibu Gulf.

75-85 mm size class had not completed the pubertal moult (Fig. 7) and the ovarian staging of these females was stage I. All of the females with more than 106 $\mathrm{mm} \mathrm{CW}$ had undergone pubertal moult during this study. The frequency of crabs with mature ovary (EX, stage III-V) increased as the body size increased. The frequency of occurrence of crabs with mature ovary

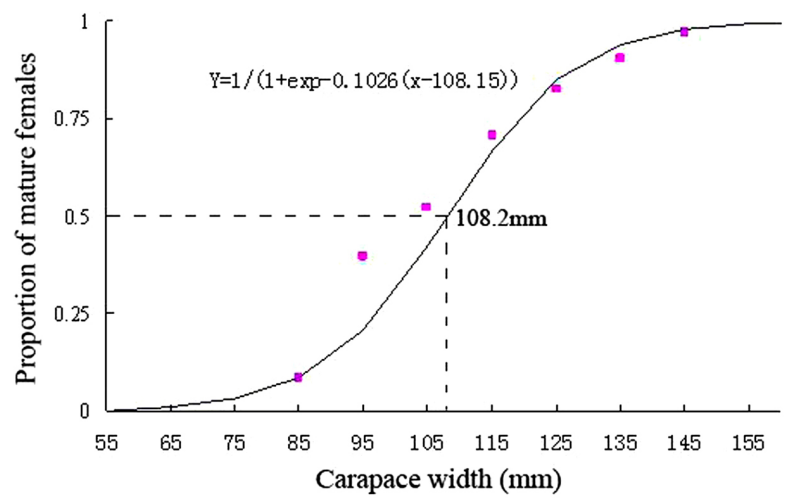

Fig. 8. - Logistic curve showing the proportion of mature Portunus pelagicus females in Beibu Gulf at each internal carapace width class (

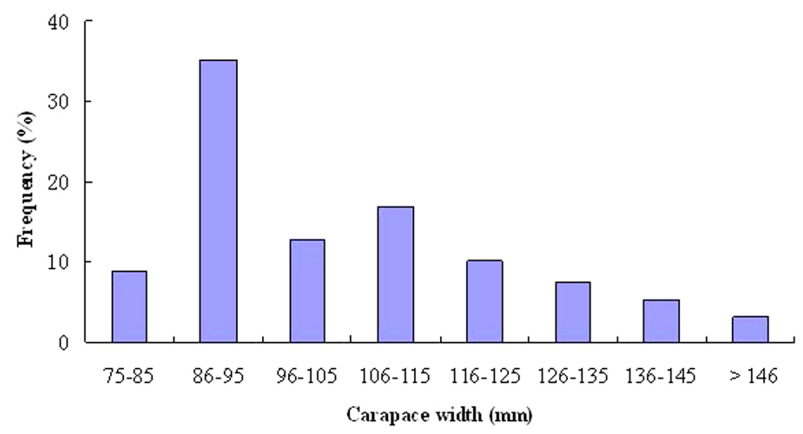

Fig. 9. - The frequency histograms for the carapace width of adult females of Portunus pelagicus in Beibu Gulf.

increased above $106 \mathrm{~mm} \mathrm{CW} \mathrm{( \geq 84.6 \% )} \mathrm{(Fig.} \mathrm{7).} \mathrm{The}$ $\mathrm{CW}$ at which $50 \%$ of females were mature $\left(\mathrm{CW}_{50}\right)$ was estimated to be $108.2 \mathrm{~mm}$, while $95 \%$ of mature females were found to be mature at $136.9 \mathrm{~mm}$ (Fig. 8).

\section{Size distribution}

The size distribution of $P$. pelagicus in Beibu Gulf is given in Figures 9 and 10. The CW of adult females ranged from 78.5 to $162.0 \mathrm{~mm}$, and the dominant size classes were 86-95, 106-115 and 96-105 mm, which included $64.9 \%$ of total adult females, while the proportion of females with $>146 \mathrm{CW}$ accounted for $3.1 \%$ only. BW of the crabs ranged from 32.5 to $372 \mathrm{~g}$, and the dominant size class was 30-60 g, which accounted for $43.2 \%$. In the majority of adult females BW was $40-120 \mathrm{~g}(71.4 \%)$, while BW $>120 \mathrm{~g}$ or $<40 \mathrm{~g}$ only accounted for $22.9 \%$ and $5.7 \%$, respectively.

\section{Monthly variation of the ovarian development and the percentage of ovigerous females}

All the ovarian stages were represented in the samples in September-December except in October (Table 
Table 4. - The percentage of different ovary development stages in Portunus pelagicus from Beibu Gulf.

\begin{tabular}{|c|c|c|c|c|c|c|}
\hline \multirow[b]{2}{*}{ Month } & \multirow[b]{2}{*}{$\mathrm{n}$} & \multicolumn{5}{|c|}{ Stages of ovary } \\
\hline & & I & II & III & IV & V \\
\hline Sep & 30 & 13.3 & 20.0 & 50.0 & 10 & 6.7 \\
\hline Oct & 30 & 6.7 & 33.3 & 53.3 & 6.7 & 0 \\
\hline Nov & 30 & 23.3 & 33.3 & 33.3 & 6.7 & 3.3 \\
\hline Dec & 32 & 9.4 & 25.0 & 50.0 & 12.5 & 3.1 \\
\hline Jan & 50 & 0 & 20.0 & 56.0 & 20.0 & 4.0 \\
\hline Feb & 59 & 0 & 5.1 & 41.0 & 27.9 & 23.7 \\
\hline Mar & 40 & 0 & 0 & 22.5 & 50.0 & 27.5 \\
\hline Apr & 34 & 0 & 0 & 41.2 & 47.0 & 11.8 \\
\hline May & 31 & 0 & 16.1 & 58.1 & 19.3 & 6.5 \\
\hline
\end{tabular}

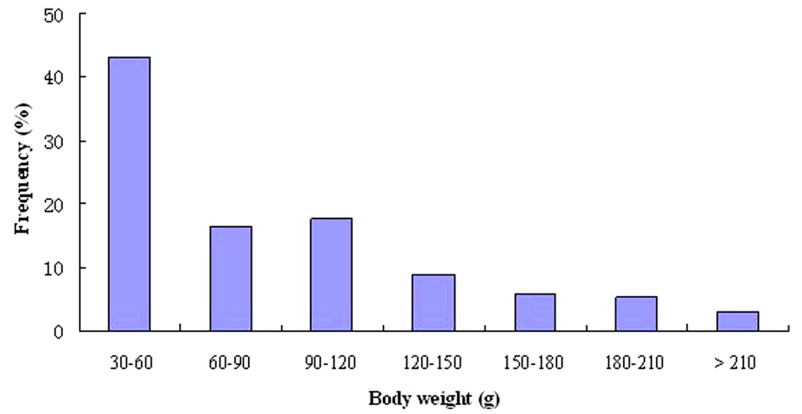

Fig. 10. - The frequency histograms for the body weight of adult females of Portunus pelagicus in Beibu Gulf.

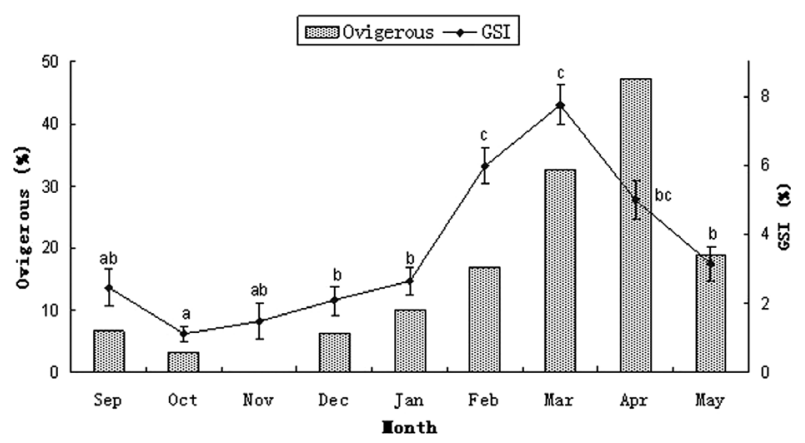

Fig. 11. - The monthly variation of the GSI and the percentage of ovigerous females of Portunus pelagicus in Beibu Gulf. The diamonds with different letters indicate significant differences between the months $(\mathrm{P}<0.05)$.

4) and in the rest of the months the majorities were in stages III-V. The highest percentage of stage $\mathrm{V}$ ovary was recorded in February and March $(23.7 \%$ and $27.5 \%$, respectively). The mean GSI of adult females peaked at $7.74 \%$ in March, and the primary spawning period was found between January and May, as at least $10 \%$ of adult females were ovigerous during this period and their GSI varied from $0.58 \%$ to $9.01 \%$ (Fig. 11).

\section{DISCUSSION}

\section{Ovarian development and staging}

The cycle of ovary and oocyte development of $P$. pelagicus has been reported by several researchers (Bawab and El-Sherief 1988, Sheild and Wood 1993, Sumpton et al. 1994, Sukumaran and Neelakantan 1998, Stewart et al. 2007). However, their criteria of ovarian staging of $P$. pelagicus are quiet different. For example, Bawab and El-Sherief (1988) classified the ovarian cycle of $P$. pelagicus into eight stages based on morphological changes of female spermatheca and copulation, while Stewart et al. (2007) divided the developing ovary into four stages based on histological studies and oogenesis. A reliable and feasible criterion for ovarian staging is necessary and important for the fishery management and hatchery seed production of $P$. pelagicus. This study is the first one to develop a comprehensive method for the ovarian staging of $P$. pelagicus by combining gonadosomatic index (GSI), pubertal moult, changes of external features and histology of ovaries. The results revealed that the females develop their ovaries via proliferation and differentiation of the oogonia prior to the pubertal moult, and this finding was supported by the fact that a few previtellogenic oocytes appeared in the late stage I. Similar findings have been reported for the other portunid species, i.e. the swimming crab Portunus trituberculatus (Wu et al. 2007), the mud crab Scylla serrata (Quinitio et al. 2007) and the mud crab Scylla ovivacae (Islam et al. 2010). The ovarian stage II is a transition from PR and EN to EX for P. pelagicus, and females with stage II ovary were generally post-pubertal moult. However, Stewart et al. (2007) divided the spawn-spent females into stage I of ovarian maturation of $P$. pelagicus, while Kumar et al. (2003) classified the ovigerous females into a separate stage. These results are inconsistent with our staging criterion. In newly spent females the dominant oocyte types were EN and PR rather than OG. Therefore, it is better to include the newly spent females in stage II. The ovarian morphology and histology of berried females of $P$. pelagicus revealed that they develop ovaries during the incubation period and the ovary stages varied between stages II-IV.

Normally, the ovary of post-puberty moult females is stage II or more advanced stages because copulation and deposition of sperms in the spermatheca can accelerate the ovarian development of portunid crabs (Yao et al. 2007). However, it was observed that from September to December there were still some females with stage I ovaries after the pubertal moult. This may be due to unsuccessful copulation in these females as soon as they completed the pubertal moult. Ovary colour progressively changed from transparent/translucent (stage I) to deep yellow or red-orange (stage V) during the course of their maturation because of the accumulation in the ovaries of carotenoids in the form of chromoproteins (Kalinina et al. 2008). However, the colour of the ovary is not strictly related to the developmental stage, particularly for the late stage I and stage 
Table 5. - Comparative findings of the reproductive biology of female Portunus pelagicus from different locations around the world.

\begin{tabular}{|c|c|c|c|c|c|c|c|}
\hline Location & $\begin{array}{l}\text { Latitude, } \\
\text { altitude }\end{array}$ & $\begin{array}{l}\text { Minimum } \\
\mathrm{CW} \text { at } \\
\text { maturity }\end{array}$ & $\begin{array}{l}\mathrm{CW} \text { at } 50 \% \\
\text { maturity / } \\
\text { mean } \mathrm{CW}\end{array}$ & $\begin{array}{l}\text { Peak of } \\
\text { mating }\end{array}$ & $\begin{array}{l}\text { Peak of ma- } \\
\text { ture crab }\end{array}$ & Ovigerous peak & Source \\
\hline Carpentaria Gulf & $\begin{array}{c}16^{\circ} 25^{\prime} \mathrm{S} \\
139^{\circ} 44^{\prime} \mathrm{E}\end{array}$ & 60 & 72.2 & --- & July-Oct & Aug-Oct & Weng (1992) \\
\hline Moreton Bay & $\begin{array}{c}27^{\circ} 20^{\prime} \mathrm{S} \\
153^{\circ} 10-20^{\prime} \mathrm{E}\end{array}$ & 79 & 106 & Oct-May & Jul-Sep & Aug-Sep, Feb-Mar & $\begin{array}{l}\text { Weng (1992); } \\
\text { Shields and Wood(1993) }\end{array}$ \\
\hline Shark Bay & $\begin{array}{l}25^{\circ} 40^{\prime} \mathrm{S} \\
113^{\circ} 41^{\prime} \mathrm{E}\end{array}$ & 61 & 92 & --- & No pattern & Jun-Aug, Dec-Jau & de Lestang et al. (2003b) \\
\hline Peel-Harvey & $\begin{array}{l}32^{\circ} 39^{\prime} \mathrm{S} \\
115^{\circ} 40^{\prime} \mathrm{E}\end{array}$ & 61 & 97.5 & --- & Oct-Dec & Nov-Feb & $\begin{array}{l}\text { de Lestang et al. (2003b) } \\
\text { Potter et al. (1983) }\end{array}$ \\
\hline $\begin{array}{l}\text { Leschenault } \\
\text { Estuary }\end{array}$ & $\begin{array}{l}33^{\circ} 15^{\prime} \mathrm{S} \\
115^{\circ} 42^{\prime} \mathrm{E}\end{array}$ & 84 & 98.0 & ---- & Sep-Nov & Dec-Jau & de Lestang et al. (2003b) \\
\hline Cochin & $\begin{array}{l}9^{\circ} 58^{\prime} \mathrm{N} \\
76^{\circ} 15^{\prime} \mathrm{E}\end{array}$ & --- & 95 & --- & Dec-Mar & Aug-Apr & Pillai and Nair (1971) \\
\hline Madras & $\begin{array}{l}13^{\circ} 05^{\prime} \mathrm{N} \\
80^{\circ} 18^{\prime} \mathrm{E}\end{array}$ & --- & 96 & --- & Nov, Jan, Jun & Sep-May & Rahaman (1967) \\
\hline Karnataka coast & $\begin{array}{c}12^{\circ} 57^{\prime}-14^{\circ} 47^{\prime} \mathrm{N} \\
74^{\circ} 6-48^{\prime} \mathrm{E}\end{array}$ & --- & 96 & --- & Dec-Feb & Aug-Sep, Feb-Mar & $\begin{array}{l}\text { Dineshbabu et al. (2008) } \\
\text { Sukumaraan and } \\
\text { Neelakantan (1998) }\end{array}$ \\
\hline Beibu Gulf & $\begin{array}{l}19^{\circ} 58^{\prime} \mathrm{N} \\
109^{\circ} 45^{\prime} \mathrm{E}\end{array}$ & 78.5 & 108.2 & Sep-Nov & Feb-May & Mar-Apr & Present study \\
\hline Abu Kir Bay & $\begin{array}{l}31^{\circ} 18^{\prime} \mathrm{N} . \\
30^{\circ} 9^{\prime} \mathrm{E}\end{array}$ & 80 & --- & ---- & Apr-Sep & May, Sep & $\begin{array}{l}\text { Bawab and El-sherief } \\
\text { (1988) }\end{array}$ \\
\hline
\end{tabular}

II, and stages IV and V. In some cases in our study the female $P$. pelagicus had a similar ovary colour in early stages between late stage I and stage II, and in advanced stages IV and stage V. In categorizing ovarian stages, apart from external characteristics of the ovary (colour, size, shape, etc.), ovarian histology, gonadosomatic index (GSI) and pubertal moult must also be taken into consideration. Our findings have shown that the percentage of different types of germinal cells, oocyte diameter, ovarian morphology (size, colour and shape, etc.) and GSI are four important aspects that should be taken into account in classifying the ovarian stages of $P$. pelagicus and that will be useful as benchmarks in future studies.

\section{GSI and HSI during ovarian maturation}

From ovarian stage II to stage III, the HSI declined significantly and GSI increased by 3.9 times. During the fast ovarian development of $P$. pelagicus (stages II-III), the nutrient reserve in the hepatopancreas was used to support the developing ovary, which led to a decrease in HSI during this period. A similar phenomenon was reported in the Chinese mitten crab, Eriocheir sinensis (Yu et al. 2007), and the swimming crab, Portunus trituberculatus (Wu et al. 2007). The positive correlation of GSI and long oocyte diameters suggested that the oocyte diameter could be used to predict the female GSI based on regression analysis (Fig. 6). Ovarian staging through in vivo examination of ovary using a biopsy method (Quinitio et al. 2007) would help researchers to predict spawning without sacrificing the female crabs (Table 2). This is important for the future hatchery seed production and reproductive studies on $P$. pelagicus, as mature or nearly maturing females are very expensive in some Asian countries (Stewart et al. 2007, Wu et al. 2010).

\section{Size at maturity and size distribution}

The minimum size at the first maturity of female $P$. pelagicus in Beibu Gulf was $78.5 \mathrm{~mm} \mathrm{CW}$, which is in conformity with the studies carried out in different parts of the world. Generally, the minimum $\mathrm{CW}$ at the first maturity of $P$. pelagicus tends to be inversely related to water temperature (Weng 1992, De Lestang et al. 2003b). In tropical regions, the species mature at smaller sizes than in subtropical and temperate waters. The $\mathrm{CW}$ at $50 \%$ female $P$. pelagicus maturity in Beibu Gulf (108.2 mm) was close to that of the Moreton Bay population $(106 \mathrm{~mm})$, but higher than that of three Western Australian and Indian populations (Table 5). This difference reflects not only inter-regional differences in the reproductive biology of female $P$. pelagicus but also differences in fishing pressure, sampling gears, sampling locations and seasons, crab density, predation pressure and food availability of natural habitat (Hines 1989, Weng 1992, de Lestang et al. 2003b, Smith et al. 2004, Johnson et al. 2010).

Previous studies have shown that the minimum legal CW of captured crabs could be roughly based on $\mathrm{CW}_{50}$ (Islam et al. 2010, Overton and Macintosh 2002). Johnson et al. (2010) suggested that, in order to protect spawning females, the minimum legal $\mathrm{CW}$ of females should be more than $\mathrm{CW}_{50}$. As the size at first maturity of $P$. pelagicus is regional and area-specific, the minimum legal sizes of CW vary accordingly (Kangas 2000). For example, the minimum legal size of P. pelagicus is $127 \mathrm{~mm} \mathrm{CW}$ (including lateral spines) for both commercial and recreational fishers in Western Australia, but it is $150 \mathrm{~mm} \mathrm{CW}$ in Queensland, Australia, and the population of Moreton Bay was composed of approximately $8 \%-10 \%$ of total adult females up to $150 \mathrm{~mm}$ (Weng 1992). In the present study fewer than $2 \%$ of total adult females $\geq 150 \mathrm{~mm} \mathrm{CW}$ were found in the Beibu Gulf population of $P$. pelagicus, whereas 
from the same region Wang et al. (2001) reported that $10 \%-20 \%$ of total adult females had a $C W \geq 150 \mathrm{~mm}$. These findings give a clear indication that the Beibu Gulf population of $P$. pelagicus have undergone high fishing pressure during the past decade, leading to the decline of the proportion of large crabs (Huang 2009). At present no management plans are in place for the fishery of $P$. pelagicus in Beibu Gulf: any size of adult $P$. pelagicus can be harvested during the fishing season (August 16-May 15) and it is now essential to implement more feasible management regulations to protect spawner-recruitment in the region.

\section{Seasonality of ovarian development and spawning}

The seasonal pattern of $P$. pelagicus spawning is known to be highly variable between geographic locations (Table 5). Gonadosomatic index (GSI) is a good indicator for the ovarian development of crustaceans (Wu et al. 2007), and in the present study a maximum was recorded in March for the Beibu Gulf population of $P$. pelagicus females. In low-latitude regions, the GSI of female $P$. pelagicus peaked earlier than that in high latitude regions (Smith and Sumpton 1989, Sumpton et al. 1994). It is known that water temperature is considered as a controlling factor for ovarian development and spawning of $P$. pelagicus (Potter et al 1983, de Lestang et al. 2003b). Huang et al.(2008) reported that in winter (December to February) the seawater temperature for the present study area was $18-20^{\circ} \mathrm{C}$ (Huang et al. 2008). However, female $P$. pelagicus can spawn at $18^{\circ} \mathrm{C}$ but no eggs would hatch out at that temperature after 68 days of incubation (Campbell 1984). The peak of ovigerous females occurred in April for the Beibu Gulf population of $P$. pelagicus females, which may be due to the accumulation of their spawning from January to April. Weng (1992) and Sheild and Wood (1993) reported that after the copulation, the ovary of $P$. pelagicus develops fast. The stage II ovary is a very short phase after pubertal moult and mating, which actually are the transition phase from PR/EN to EX for the ovary, and ovarian stage II of $P$. pelagicus lasted only 2-7 days with water temperature between $26^{\circ} \mathrm{C}$ and $32^{\circ} \mathrm{C}$ with feeding (Wu et al. unpublished). Therefore, the high proportion of stage II females during the period September-December indicates that the first pubertal moult and mating may occur intensively during this period for females of less than 1 year. The highest number of spawners is found in February-May, but berried crabs are recorded throughout the year in Beibu Gulf.

\section{CONCLUSION}

Based on pubertal moult, GSI, morphology and histological studies, ovarian development in $P$. pelagicus can be divided into five stages The differences in reproductive biology of female $P$. pelagicus indicate that these reproductive parameters are geography-specific. This is the first study to report the reproductive biology of female $P$. pelagicus from the Beibu Gulf population and the variation in reproductive performance of female $P$. pelagicus is specific to the geographical area.

\section{ACKNOWLEDGEMENTS}

This study was supported by a grant from the National High Technology Research R and D Programme of China (Programme 863) (No. 2012AA10A409) and an Open-end Fund (No.2008HS001) from Jiangsu Key Laboratory of Marine Biotechnology, Huaihai Institute of Technology. Infrastructure costs were partially supported by Shanghai University Knowledge Service Platform (No.ZF1206) of Shanghai Municipal Education Commission. The authors express their sincere gratitude to Professor Aiming Wang of Hainan University for his great help in obtaining the crab samples for the study.

\section{REFERENCES}

Bawab F., El-Sherief S. 1988. Stages of the Reproductive Cycle of the Female Crab Portunus pelagicus (L., 1758) Based On the Anatomical Changes of the Spermatheca (Decapoda Brachyura, Portunidae). Crustaceana 54: 139-148. http://dx.doi.org/10.1163/156854088X00041

Bureau of Fisheries (ed) 2010. China Fisheries Yearbook of 2009. Ministry of Agriculture of China, Beijing, China. (in Chinese).

Campbell G. 1984. A comparative study of adult sexual behaviour and larval ecology of three commercially important portunid crabs from the Moreton Bay region of Queensland, Australia. $\mathrm{PhD}$ thesis, University of Queensland, Australia, Brisbane, Queensland, Australia, $253 \mathrm{pp}$.

De Lestang S., Hall N., Potter I. 2003a. Changes in density, age composition, and growth rate of Portunus pelagicus in a large embayment in which fishing pressures and environmental conditions have been altered. J. Crustac. Biol. 23: 908-919. http://dx.doi.org/10.1651/C-2376

De Lestang S., Hall N., Potter I. 2003b. Reproductive biology of the blue swimmer crab (Portunus pelagicus, Decapoda: Portunidae) in five bodies of water on the west coast of Australia. Fish. Bull. 101: 745757.

Dineshbabu A., Shridhara B., Muniyappa Y. 2008. Biology and exploitation of the blue swimmer crab, Portunus pelagicus (Linnaeus, 1758), from south Karnataka coast, India. Indian J. Fish. 55(3): 215-220.

Dixon C., Hooper G. 2009. Blue crab (Portunus pelagicus) fishery 2007/08. Stock assessment report to PIRSA fisheries. South Australian Research and Development Institute (Aquatic science), Adelaide. F2007/000729-5.

Hines A. 1989. Geographic variation in size at maturity in brachyuran crabs. Bull. Mar. Sci. 45: 356-368.

Huang Z. 2009. Species composition and quantitative distribution of crabs in the northern continental shelf of South China Sea. J. Dalian. Fish. Univ, 24(6): 553-558. (in Chinese with English abstract).

Huang Y., Li Y., Shao H., et al. 2008. Seasonal Variations of sea surface temperature, Chlorophyll- $a$ and turbidity in Beibu Gulf, MODIS imagery study. J. Xiamen. Univ. (Nat. Sci.) 47(6): 856862. (in Chinese with English abstract).

Islam M., Kodama S., Kurokura H. 2010. Ovarian development and size at maturity of the mud crab Scylla olivacea in Pak Phanang mangrove swamps, Thailand. Mar. Biol. Res. 6: 503-510. http://dx.doi.org/10.1080/17451000903335113

Johnson D., Gray C., Macbeth. W. 2010. Reproductive biology of Portunus pelagicus in a south-east Australian estuary. J. Crustac. Biol. 30: 200-205. http://dx.doi.org/10.1651/08-3076.1

Kalinina M., Vinnikova N., Semen K. 2008. Gonadogenesis and color characteristics of ovaries in Japanese mitten crab Eriocheir japonicus. Russ. J. Dev. Biol. 39: 52-58. http://dx.doi.org/10.1134/S1062360408010086

Kangas M. 2000. Synopsis of the biology and exploitation of the blue swimmer crab, Portunus pelagicus Linnaeus, in Western Australia. Fish. Res. Rep. Fish. West. Aust. 121: 1-22.

Kumar M., Xiao Y., Venema S., et al. 2003. Reproductive cycle of the blue swimmer crab, Portunus pelagicus, off southern Australia. J. Mar. Biol. Assoc. U.K. 83: 983-994. http://dx.doi.org/10.1017/S0025315403008191h 
Maheswarudu G., Josileen J., Nair K., et al. 2008. Evaluation of the seed production and grow out culture of blue swimming crab Portunus pelagicus (Linnaeus, 1758) in India. Indian J. Mar. Sci. 37: 313-321.

Overton J., Macintosh. D. 2002. Estimated size at sexual maturity for female mud crabs (genus Scylla) from two sympatric species within the Ban Don Bay, Thailand. J. Crustac. Biol. 22: 790-797. http://dx.doi.org/10.1163/20021975-99990293

Pillay K., Nair N. 1973. Observations on the biochemical changes in gonads and other organs of Uca annulipes, Portunus pelagicus and Metapenaeus affinis (Decapoda: Crustacea) during the reproductive cycle. Mar. Biol. 13: 167-198. http://dx.doi.org/10.1007/BF00367985

Potter I., Chrystal P., Loneragan N. 1983. The Biology of the Blue Manna Crab Portunus pelagicus in an Australian Estuary. Mar. Biol. 78: 75-85. http://dx.doi.org/10.1007/BF00392974

Quinitio E., De Pedro J., Estepa F. 2007. Ovarian maturation stages of the mud crab Scylla serrata. Aquac. Res. 38: 1434-1441. http://dx.doi.org/10.1111/j.1365-2109.2007.01650.x

Rahaman A.A. 1967. Reproductive and nutritional cycles of the crab Portunus pelagicus (Linnaeus) (Decapoda: Brachyura) of the Madras coast. Proc. Indian Acad. Sci. Sec. B 65: 76-82.

Romano N., Zeng C. 2008. Blue swimmer crabs, emerging species in Asia. Glob. Aquacul. Advoc. 11: 34-36.

Sukumaran K., Neelakantan B. 1998. Mortality and stock assessment of two marine portunid crabs, Portunus (Portunus) sanguinolentus (Herbst) and Portunus (Portunus) pelagicus (Linnaeus) along the southwest coast of India. Indian J. Fish. 43: 225-240.

Shields J., Wood F. 1993. Impact of parasites on the reproduction and fecundity of the blue sand crab Portunus pelagicus from Moreton Bay, Australia. Mar. Ecol. Prog. Ser. 92: 159-170. http://dx.doi.org/10.3354/meps092159

Smith G., Sumpton. W. 1989. Behavior of the commercial sand crab Portunus pelagicus (L.) at trap entrances. Asian Fish. Sci. 3: 101-113.

Smith K., Hall N., de Lestang S., et al. 2004. Potential bias in estimates of the size of maturity of crabs derived from trap samples.
Ices. J. Mar. Sci, 61: 906-912. http://dx.doi.org/10.1016/j.icesjms.2004.07.019

Stewart M., Soonklang N., Stewart P., et al. 2007. Histological studies of the ovaries of two tropical portunid crabs, Portunus pelagicus (L.) and Scylla serrata (F.). Invertebr. Reprod. Dev. 50: 85-97. http://dx.doi.org/10.1080/07924259.2007.9652231

Sumpton W., Potter M., Smith G. 1994. Reproduction and growth of the commercial sand crab, Portunus pelagicus (L.) in Moreton Bay, Queensland. Asian Fish. Sci. 7: 103-113.

Wang, H., Wu H., Wang Z., et al. 2001. Fisheries biology of Portunus pelagicus Linneaus initialing investigation. Mar. Sci, 25: 36-39 (in Chinese with English abstract).

Weng H. 1992. The sand crab (Portunus pelagicus) populations of two different environments in Queensland. Fish. Res. 13: 407-422. http://dx.doi.org/10.1016/0165-7836(92)90061-W

Wu X., Yao G., Yang X., et al. 2007. A study on the ovarian development of Portunus trituberculatus in East Sea during the first reproductive cycle. Acta. Oceanol. Sin. 29: 120-127 (in Chinese with English abstract).

Wu X., Zhou B., Cheng Y., et al. 2010. Comparison of gender differences in biochemical composition and nutritional value of various edible parts of the blue swimmer crab. J. Food Compos. Anal. 23: 154-159. http://dx.doi.org/10.1016/j.jfca.2009.08.007

Xiao Y., Kumar M. 2004. Sex ratio, and probability of sexual maturity of females at size, of the blue swimmer crab, Portunus pelagicus Linneaus, off southern Australia. Fish. Res. 68: 271-282. http://dx.doi.org/10.1016/j.fishres.2003.11.012

Yao G., Wu X., Yang X., et al. 2007. Ovarian development of swimming crab, Portunus trituberculatus. Zool. Res. 28: 423-429 (in Chinese with English abstract)

Yu Z., Wu X., Chang G., et al. 2007. Changes in the main biochemical composition in ovaries and hepatopancreas of Chinese mitten crab, Eriocheir sinensis (H. Milne-Edwards), during the second ovarian development. Acta. Hydrobiol. Sin. 31: 45-52. (in Chinese with English abstract). 